\title{
Performance of West African Dwarf (WAD) Goats Fed Urea Treated Maize Offal as Supplement to Natural Herbage.
}

\author{
BARDE* ${ }^{*}$ R.E ${ }^{1}$., AYA,V.E' .,ARI,M.M ${ }^{1}$.,MUSA,M ${ }^{1}$ and YAKUBU, A $^{2}$
}

${ }^{1}$ Animal Science Department, College of Agriculture Lafia, Nigeria ${ }^{2}$ Faculty of Agriculture, Nasarawa State University Keffi, Nigeria *Correspondence: rowebarde@yahoo.com 08035304913

\section{SUMMARY}

West African Dwarf (WAD) goats grazing natural herbage were supplemented with different levels of urea treated maize offal (UMO) to determine their performance. The maize offal were treated at $0 \%$ UMO, $4 \% \mathrm{UMO}, 6 \% \mathrm{UMO}$ and $8 \%$ UMO representing $0,4,6$ and $8 \%$ of urea respectively. Naturally grazing twenty WAD bucks aged between 7 and 9 months weighing 8.7 $\pm 1.5 \mathrm{~kg}$ were randomly allocated to five supplementary diets (0\% UMO, 4\% UMO, 6\% UMO and 8\% UMO) in a completely randomized design lasting 84 days to determine the effect of the supplementation. Significant $(\mathbb{P}<0.05)$ mean weight gained of $5.30 \mathrm{~kg}$ was recorded for goats on 4\%UM0; Similarly, lowest $(P<0.05)$ feed conversion ratio of 7.28 was obtained for $4 \% \mathrm{UMO} 0$ and better benefit of $\mathrm{N} 3,170$ per live weight gain was recorded for goats on the same $4 \%$ urea treatment. Though the different levels of urea treatment of maize offal recorded significant $(P<0.05)$ increase in blood urea, they were below the toxic concentration level of $10 \mathrm{mg}$ per litre; and superior performance was recorded for WAD goats fed $4 \%$ of UMO supplement.

Key words: Maize offal, urea, herbage, goats

\section{INTRODUCTION}

In Nigeria, West African Dwarf (WAD) goats are raised under the traditional system where they graze natural pasture during dry season while during the cropping seasons they are tethered. This system induces feed stress and the herbage they graze has a low protein content of between 2-5 percent (Uza et al., 2005). These goats are kept by small holder framers because they have compact body, short generation interval, are easy to handle and have the ability to convert roughage to edible meat. These ruminants like other living organisms need nutrients to build, maintain the body's structure and supply energy for vital activities. Protein tends to be the most expensive. The safest, simplest and cheapest source is the non protein nitrogen urea. It has been reported that one hundred grammes of urea are equivalent to $200 \mathrm{~g}$ of digestible protein provided the remainder of the ration supplies enough readily usable energy (McDonald et al., 1995). The cereal and tuber starches appear to be the best but for its high cost and demand by humans and mono gastric animals.

Maize (Zea mays) is grown throughout the world as a staple food crop, maize offal as a waste represents most of the leftover of maize grain processing from both wet and dry milling. Many workers (Chesworth, 1992; McDonald et al., 1995; Uza et al., 2005) have identified urea as the safest and cheapest of the non-protein nitrogen (NPN) compound to release ammonia for rumen microbes to create new proteins. This high caloric maize offal (waste) could be combined with complementary cheap protein source (urea) that can satisfy the maintenance and growth requirements of the ruminant animal like other expensive conventional cereal feeds. It is against this back drop that this study is designed to evaluate the different levels of urea treated maize offal as a supplement to WAD goats grazing natural herbage.

\section{MATERIALS AND METHODS Location}

The experiment was conducted at the Small Ruminant Unit of the livestock complex of the College of Agiculture, Lafia. Nasarawa State, Nigeria. Lafia is located Latitude N $08^{\circ}$ 
29'8.66"; Longitude E $008^{\circ} 29^{\prime} 49.10^{\prime \prime}$ and Altitude $164.5 \mathrm{~m}$; in the guinea savannah vegetation, with is sandy loam soil texture (Alewu et al., 2007) .

\section{Urea treatment of maize offal}

Maize offal was obtained from open market in Lafia, Nasarawa State. Three levels of urea solution: 4, 6 and 8 percent were prepared by dissolving 40,60, and 80 grammes of fertilizer grade urea in $200 \mathrm{ml}$ of water for every $\mathrm{kg}$ of maize offal according to the method of Chesworth (1992) representing 4,6 and $8 \%$ urea concentration. Fifty kilogrammes each of maize offal was sprayed (garden sprayer) with 10 litres of one of the three urea levels solution, sealed and made air tight with plastic sheeting covered with a layer of earth on impervious floor and left undisturbed for twenty one days to allow the ammonia produce by hydrolysis of urea diffuse through the material (Uza et al., 2005).

\section{Experimental Animals and their Management}

Twenty WAD bucks aged between 7 and 9 months weighing $8.7 \pm 1.5 \mathrm{~kg}$ were obtained from the herd at the farm and routinely given Ivomec ${ }^{\circledR}$ injection against endo and ecto parasites before the start of the experiment. Four bucks were randomly allocated to five treatments (T1, natural herbage only; $\mathrm{T} 2$, natural herbage $+0 \%$ urea treated maize offal; T3, natural herbage $+4 \%$ urea treated maize offal; $\mathrm{T} 4$, natural herbage $+6 \%$ urea treated maize offal and $\mathrm{T} 5$, natural herbage $+8 \%$ urea treated maize offal) in a completely randomized design format.

The bucks were housed in individual pens measuring $1.5 \mathrm{~m}^{2}$ each with feeding and watering troughs. The animals were tagged and allowed access to water and mineral salt lick ad libitum. Supplement diets were offered to animals between the hours of 0900 and 1100 hours before they were zero grazed the natural herbage for a period of 84 days. The natural herbage was harvested at 1800 hours daily and allowed to stay overnight before the next day's feeding to check frothy bloat.
The animals were weighed at the beginning of the experiment and weekly thereafter for twelve weeks to assess live weight changes. Supplement and forage intake were determined by subtracting refusal from quantity offered.

\section{Data collection}

Body weights were taken weekly; daily water intake, feed consumption and feed refusal were weighed every morning between 0800 and 0900 hours for 84 days. Blood collection was done before commencement of feeding trial and monthly thereafter for laboratory urea analysis.

\section{Cost benefit analysis}

Potential benefit of WAD goat fed UMO as supplement was analysed (Dixon et al., 1989). This analysis focused on the monetary returns that accrued from the sales of WAD goats for meat. Gross monetary benefit, cost, and benefit-cost ratio (BCR) were determined.

\section{Chemical analysis}

Samples of untreated maize offal, treated maize offal, grazed herbage and faecal materials were oven dried to a constant weight and milled. Ten grammes each of the samples were analyzed for proximate components and nitrogen by AOAC. (1980) procedure. Blood urea was analyzed by Bertholet Urease methods (Tietz, 1987).

\section{Statistical analysis}

Means of feed intake, weight gained, Feed conversion ratio (FCR), blood urea intake were subjected to analysis of variance and significant means were separated using Duncan's multiple range test (SPSS, 2007).

\section{RESULTS}

The chemical compositions of experimental diets are presented in Table I. Crude protein of herbage consumed was $13.78 \%$, while CP of the treated maize offal increased with ammonization from $17.34 \%$ for $0 \% \mathrm{UMO}$ to $30.9 \%$ for $6 \%$ UMO. The crude fibre content of $39.94 \%$ was obtained for herbage and decreasing content of 16.56, 13.06, 12.60 and $10.92 \%$ were recorded for $0 \% \mathrm{UMO}$, 
$4 \% \mathrm{UMO}, \quad 6 \% \mathrm{UMO}$ and $8 \% \mathrm{UMO}$ respectively.

Performances of WAD goats fed supplement of urea treated maize offal is shown in Table II. Highest $(\mathrm{P}<0.05)$ mean weight gained of $5.30 \mathrm{~kg}$ was recorded for goats on $4 \% \mathrm{UMO}$, $\% \mathrm{UMO}$ was $3.09 \mathrm{~kg}$ and WAD goats on natural herbage had $2.5 \mathrm{~kg}$ gain. Similarly, lowest $(\mathrm{P}<0.05)$ feed conversion ratio of 7.28 was obtained for 4\%UMO; while varying values of $31.95,15.34$ and 18.68 were recorded for $0 \%, 6 \%$ and $8 \% \mathrm{UMO}$ respectively.
Relatively better benefit of N 3,170 per live weight gain was recorded (Table III) for goats on 4\%UMO (T3); N 2,163.0, for goats

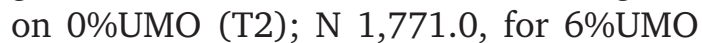
(T4); N 1,750.0 for goats on natural herbage only (T1); and $\mathrm{N} \mathrm{1,414.0}$ for those on 8\%UMO (T5).

Significant $(\mathrm{P}<0.05)$ differences in mean blood urea between the treatments (Table IV) were observed. Mean values of blood urea ranged from 4.75 to $5.99 \mathrm{mg} / 1$ before the treatment commenced and throughout the twelve weeks of feeding trial.

TABLE I. Chemical composition of experimental Diets (\%)

\begin{tabular}{|llllll|}
\hline Parameter & Herbage & $0 \% \mathrm{UMO}$ & $4 \% \mathrm{UMO}$ & $6 \% \mathrm{UMO}$ & $8 \% \mathrm{UMO}$ \\
\hline Dry Matter & 91.08 & 85.25 & 86.62 & 87.97 & 86.30 \\
Crude Protein & 13.78 & 7.26 & 17.34 & 18.57 & 30.90 \\
Crude Fibre & 39.94 & 16.56 & 13.06 & 12.60 & 10.92 \\
Lipid & 3.62 & 7.68 & 7.46 & 8.13 & 7.73 \\
Ash & 3.84 & 1.98 & 3.29 & 3.18 & 2.63 \\
N F E & 38.82 & 66.52 & 58.85 & 47.52 & 47.82 \\
Phosphorus & 0.69 & 0.02 & 0.12 & 0.11 & 0.29 \\
Calcium & 0.29 & 0.28 & 0.51 & 0.12 & 0.21 \\
\hline
\end{tabular}

N F E - Nitrogen free Extract

TABLE II. Performance of WAD bucks fed urea treated maize offal as supplement

\begin{tabular}{|lllllll|}
\hline Parameter & T1 & T2 & T3 & T4 & T5 & SEM \\
\hline No. Of bucks & 4 & 4 & 4 & 4 & 4 & - \\
Feeding period (days) & 84 & 84 & 84 & 84 & 84 & - \\
Initial mean wt $(\mathrm{kg})$ & 8.4 & 8.94 & 9.4 & 8.24 & 8.43 & 1.23 \\
Final mean wt $(\mathrm{kg})$ & $10.75 \mathrm{~b}$ & $12.03 \mathrm{~b}$ & $15.30 \mathrm{a}$ & $10.77 \mathrm{~b}$ & $10.45 \mathrm{~b}$ & 0.174 \\
Total mean wt gain $(\mathrm{kg})$ & $2.50 \mathrm{c}$ & $3.09 \mathrm{~b}$ & $5.30 \mathrm{a}$ & $2.53 \mathrm{c}$ & $2.02 \mathrm{~d}$ & 0.204 \\
Weekly wt gain $(\mathrm{kg})$ & $0.2575 \mathrm{~b}$ & $0.4412 \mathrm{a}$ & $0.2108 \mathrm{~b}$ & $0.1683 \mathrm{~b}$ & $0.208 \mathrm{~b}$ & 0.027 \\
& & & & & & \\
Total feed intake $(\mathrm{kg})$ & 3.22 & 3.62 & 3.75 & 3.58 & 3.60 & 0.554 \\
Daily forage intake $(\mathrm{kg})$ & $3.22 \mathrm{a}$ & $1.58 \mathrm{~b}$ & $2.45 \mathrm{ab}$ & $2.60 \mathrm{ab}$ & $2.67 \mathrm{ab}$ & 0.623 \\
Daily supp. Intake $(\mathrm{kg}$ & - & $2.04 \mathrm{a}$ & $1.30 \mathrm{ab}$ & $0.98 \mathrm{~b}$ & $0.93 \mathrm{~b}$ & 0.196 \\
Feed conversion ratio (FCR) & $18.11 \mathrm{ab}$ & $31.95 \mathrm{~b}$ & $7.28 \mathrm{a}$ & $15.34 \mathrm{a}$ & $18.68 \mathrm{ab}$ & 3.492 \\
\hline
\end{tabular}

SEM - Standard error mean

$a, b, c, d$ - Means on the same row with different superscript are significantly $(P<0.05)$ different 
TABLE III: Cost benefit of urea treated maize offal as supplement

\begin{tabular}{|lllllll|}
\hline Parameter & T1 & T2 & T3 & T4 & T5 & SEM \\
\hline Total forage consumed (Kg) & $67.62 \mathrm{a}$ & $33.18 \mathrm{~b}$ & $51.45 \mathrm{ab}$ & $54.60 \mathrm{ab}$ & $56.07 \mathrm{ab}$ & 0.623 \\
Total supp. consumed (kg) & - & $42.84 \mathrm{a}$ & $27.30 \mathrm{ab}$ & $20.58 \mathrm{~b}$ & $19.53 \mathrm{~b}$ & 0.196 \\
Total feed consumed (kg) & 67.62 & 76.02 & 78.75 & 75.18 & 75.60 & 0.554 \\
Total live wt gain (kg) & $2.50 \mathrm{c}$ & $3.09 \mathrm{~b}$ & $5.30 \mathrm{a}$ & $2.53 \mathrm{c}$ & $2.02 \mathrm{~d}$ & 0.204 \\
Cost of forage consumed (N) & 33.81 & 16.59 & 25.73 & 27.30 & 28.04 & - \\
Cost per kg treated supp. (N) & - & 10.25 & 14.15 & 15.35 & 16.55 & - \\
Cost of supp. Consumed (N) & - & 439.11 & 386.30 & 315.90 & 323.22 & - \\
Cost of feed consumed (N) & 33.81 & 455.70 & 412.03 & 343.20 & 351.26 & - \\
Benefit/ kg live wt gain (N) & $1,750.0$ & $2,163.0$ & $3,710.0$ & $1,771.0$ & $1,414.0$ & - \\
Benefit cost ratio (benefit/cost) & 51.76 & 4.93 & 9.00 & 5.16 & 4.03 & - \\
\hline
\end{tabular}

${ }^{*} \mathrm{~N} 700$ per kg live weight (wt). $\quad$ SEM - Standard error mean

$a, b, c, d$ - Means on the same row with different superscript are significantly $(P<0.05)$ different

TABLE IV: Effect of urea treated maize offal supplement on blood urea $(\mathrm{mg} / \mathrm{l})$

\begin{tabular}{|clllll|}
\hline Treatment & week 0 & week 4 & week 8 & week 12 & SEM \\
\hline Herbage (T1) & $4.75 \mathrm{~d}$ & $5.19 \mathrm{a}$ & $5.10 \mathrm{~b}$ & $5.02 \mathrm{c}$ & 0.0429 \\
0\%UMO (T2) & $5.20 \mathrm{~b}$ & $5.19 \mathrm{~b}$ & $5.22 \mathrm{~b}$ & $5.33 \mathrm{a}$ & 0.0195 \\
$4 \%$ UMO (T3) & $5.44 \mathrm{a}$ & $5.46 \mathrm{a}$ & $5.01 \mathrm{c}$ & $5.11 \mathrm{~b}$ & 0.0514 \\
$6 \%$ UMO (T4) & $5.45 \mathrm{c}$ & $5.50 \mathrm{~b}$ & $5.53 \mathrm{ab}$ & $5.55 \mathrm{a}$ & 0.0115 \\
8\%UMO (T5) & $5.88 \mathrm{~b}$ & $5.99 \mathrm{a}$ & $5.59 \mathrm{c}$ & $5.59 \mathrm{c}$ & 0.0457 \\
\hline
\end{tabular}

SEM=Standard error mean. a,b,c,d - Means on the same row with different superscript are significantly $(P<0.05)$ different

\section{DISCUSSION}

The $13.78 \%$ of CP contentment of herbage consumed by WAD goats in T1 compares favourably with 13.13 reported by Uza et al. (2005) for natural herbage during dry season in this guinea savannah of Nigeria. The increased CP content of UMO recorded from $7.26 \%$ for T2 to $17.34,18.57$, and 30.90 for T3, T4 and T5 respectively was as a result of the increased concentration of urea treatment. Effect of ammonization was also evident in the crude Fibre (CF) content of UMO decreasing with increased urea concentration from 16.56 for 0\%UMO to 10.92 for 8\%UMO. Similar results of solubility of fibre have been reported for different crop waste (Taiwo et al., 1992; Oliveros et al., 1993; Oduguwa et al., 1999). The total mean weight gain of $5.30 \mathrm{~kg}$ and higher feed efficiency of obtain in this study agrees with the findings of others (Chestwort, 1992; Taiwo et al., 1992; Oliveros et al., 1993 ; Oduguwa et al., 1999 and Uza et al ., 2005). The decline in performance beyond 4\% urea treatment could be attributed to lower intake of the supplement at T4 $(0.98 \mathrm{~kg})$ and T5 $(0.93 \mathrm{~kg})$ when compared to T3's $1.30 \mathrm{~kg}$.
The lower intake could be due to lack of palatability as a result of increased pungent smell of ammonia released on hydrolysis of urea at higher levels of concentration (Chestwort, 1992). WAD goats on T3 diet required only $7.28 \mathrm{~g}$ of feed for a gramme gain in weight compared to $15.34,18.11$, 18.68 and $31.95 \mathrm{~g}$ required by goats on $\mathrm{T} 4$, $\mathrm{T} 1, \mathrm{~T} 5$ and $\mathrm{T} 2$ respectively. Increased microbial degradation could be the reason for increased level of intake and improved weight gain at $4 \%$ urea treatment of maize offal than other levels and agrees with the findings of Uza et al ., (2005) that urea treatment beyond $4 \%$ does not favour efficient conversion of feed.

Similarly benefit per live weight gain in naira shows that goats on diet $\mathrm{T} 3$ recorded $\mathrm{N}$ 3,710 that is $\mathrm{N} 1,960, \mathrm{~N} 1,547, \mathrm{~N} 1,939$ and $\mathrm{N} 2,296$ better than goats on T1, T2, T4 and $\mathrm{T} 5$ respectively.

Toxicity could not have been experienced because blood urea concentration was below 10mg/l toxic level (McDonalds et al., 1995). This is an indication that the liver coped with increased urea treatment at 4, 6 
and $8 \%$.

\section{CONCLUSION}

Supplementation of WAD goats grazing natural herbage with different levels of urea treated maize offal increased the protein content of the residue from 7.26 to 17.34 , 18.57 and $30.90 \%$ for 4,6 and $8 \%$ urea treatment respectively. But the crude fibre decreased from 16.56 to $13.06,12.60$ and $10.92 \%$ in that order. And blood urea of goats fed showed no toxicity at all levels. However, superior performance and benefit were recorded for WAD goats fed $4 \%$ of urea treated maize offal supplement in this study.

\section{REFERENCES}

ALEWU V, BIMBO,L N.L., SAMAILA K.I AND MARCUS N.D (2007). Geographic Perspective of Nasarawa State. Department of Geography Nasarawa State University.157pp

A.O.A.C. (1980). Association of Official Analytical Chemist. Official method of analysis. $14^{\text {th }}$ ed. AOAC Washington DC USA 180pp

CHESWORTH ,J. (1992) Ruminant Nutrition. The Tropical Agricultural Series $1^{\text {st }}$ edition.Macmillian Press Ltd. London170pp

DIXON, J. A DAVID, J.E AND SHERMAN, P.B (1989). The Economics of Dryland Management $1^{\text {st }}$ edition, Ecarthsan Publications Ltd., London. Pp101-139.
MCDONALDS, P.,EDWARDS, R. A. AND GREENHALGH, J. F.D. (1995). Anmal Nutrition. $5^{\text {th }}$ edition. .ELSBS with Longman. 607pp

ODUGUWA, O.O., OSOBAMAIWA,O., SANI,D AND AKINTUNDE, A.Y. (1990). Effect of urea treatment on utilization of Cocoa-pod husk in Rabbit. Trop. J. Anim. Sci. 1 (2): 23-28.

OLIVEROS,B. A., BRITTON, R. A AND KLOPTENSTEIN, T. J. (1993). Ammonia and/or calcium hydroxide treatment of stover intake, digestibility and digestion kinetics, Anim. Feed Sci. And Technol., 44: 59-72.

SPSS (2007). Statistical Package for Social Science.16.0 version forWindows.www.spss.com

TAIWO, A.A., ADEBOWALE, E A.. GREENHALGH，J. F. D AND AKINSOYINU, A. O. (1992). Effects of urea treatments in the chemical composition and degradation characteristics of some crop residues. Nig, J. Anim Prod. 19: 25-35.

TIETZ,N. W. (1987). Fundamentals of Clinical Chemistry, $3^{\text {rd }}$ edition. W. B. Sander company. London. Pp577-678.

UZA, D.V., BARDE, R.E. AND AYOADE, J.A.(2005) Effect of Urea treated Cassava peels as Supplement to WAD Goats Grazing Natural Pasture. Nig.Vet. Journal 26 (1),1-9 